PAEDAGOGIA CHRISTIANA

2/26(2010) - ISSN 1505-6872

Mieczystaw Łaszczyk*

Włocławek-Toruń

\title{
Czy jest możliwy dialog we wspólnocie parafialnej?
}

Problem postawiony w tytule $\mathrm{w}$ formie pytania już na wstępie wskazuje na trudności w dialogu, a nawet stawia pod znakiem zapytania samą możliwość dialogu we wspólnocie parafialnej. Skąd bierze się ta podejrzliwość i niepewność: czy możliwy jest dialog we wspólnocie parafialnej? Na początku nasuwa się prosta hipoteza, że kryje się za tym pewne doświadczenie modelu funkcjonowania przeciętnej polskiej parafii, w której duszpasterstwo wciąż na ogół koncentruje się na księdzu. Do tego dochodzi nierzadko autokratyczny styl kierowania parafia, który z natury wyklucza dialog. W obliczu postawionego $w$ tytule zadania poszukiwania odpowiedzi uzasadnionej i w sposób w miarę usystematyzowany wydaje się, że najpierw należy rozpatrzyć zależność dialogu w parafii od trzech istotnych elementów: teologicznej wizji Kościoła, modelu funkcjonowania parafii i duszpasterstwa, stylu sprawowania funkcji kierowania. Stopniowo ukazując te związki, można będzie wykazać szanse i zagrożenia dialogu parafialnego. Jeszcze we wstępie należy określić definicję, a przynajmniej rozumienie i elementy konstytutywne dialogu.

\section{Ogólne podstawy dialogu we wspólnocie parafialnej}

Ogólne rozumienie dialogu zakłada komunikację interpersonalną, aktywne słuchanie, współuczestnictwo, współpracę i współodpowiedzialność. Są to istotne elementy szeroko pojętego dialogu. Według wstępnej definicji

* Ks. Mieczysław Łaszczyk, doktor w zakresie teologii pastoralnej, adiunkt na Wydziale Teologicznym UMK, proboszcz parafii Choceń w diecezji włocławskiej. 
Encyklopedii katolickiej KUL: dialog to „rozmowa mająca na celu wzajemne konfrontacje i rozumienie poglądów, a także współdziałanie w zakresie wspólnego poszukiwania prawdy, obrony wartości ogólnoludzkich i współpracy dla sprawiedliwości społecznej i pokoju" . Dialog zatem można rozumieć różnie: w sensie psychologicznym, socjologicznym, religijnym. W odniesieniu do parafii łatwiej może określić, czym nie jest i z czym nie da się pogodzić dialogu we wspólnocie parafialnej. Można z góry stwierdzić, że dialog nie jest dyskusja, moralizowaniem, osądzaniem, przesłuchiwaniem, monologiem, nie da się pogodzić z autokratyzmem, paternalizmem, ekskluzywizmem i sekciarstwem. $Z$ czym zaś kojarzy się dialog we wspólnocie od strony pozytywnej? Jest on wzajemną wymianą darów, umiejętności, talentów. Jest ubogacaniem przez siebie partnerów. Zakłada wzajemną otwartość stron zarówno na dawanie, jak i przyjmowanie. W tym sensie jest służeniem sobie nawzajem. Kluczowa jest tu postawa pokory, zaufania i ,miłości-agape". Jako skutek autentycznego dialogu wytwarza się swoista więź i solidarność międzyludzka. W parafii jednak jako wspólnocie eklezjalnej elementy natury psychologicznej czy socjologicznej nie wystarczą. W podstawach dialogu we wspólnocie parafialnej należy uwzględnić aspekt teologiczny. Najpierw trzeba wymienić główne źródło dialogu, którym jest sam Bóg. On prowadzi specyficzny dialog we wspólnocie Trójcy Osób, stwarza na swój obraz i podobieństwo partnera dialogu ze Sobą - człowieka, kontynuuje wspaniałomyślnie w swoim Synu Jezusie Chrystusie dialog przebaczenia i miłości miłosiernej z niewiernym, nieposłusznym i grzeszącym pychą człowiekiem. W Bogu-Człowieku buduje wspólnotę dialogu z Sobą i między ludźmi - Kościół.

Chrześcijanie wierzą, że pełny dialog jest możliwy w Jezusie Chrystusie. Jak mówił Jan Paweł II: „,nie można zrozumieć człowieka do końca bez Chrystusa, ani jego historii, ani kim jest, skąd przychodzi i dokąd zmierza"2. Ludzkie możliwości urzeczywistniania dialogu istnieją, ale są ograniczone i są uwarunkowane wieloma czynnikami. Wśród nich można wymienić predyspozycje moralne, zdolności intelektualne, wrażliwość emocjonalną, dyspozycję woli, cechy charakteru, kulturę osobista, uwarunkowania środowiskowe i wychowawcze itp. W dialogu we wspólnocie parafialnej trzeba i można na nich bazować, ale nie wolno tylko do nich się ograniczyć. Istnieje w tym dialogu pole na działanie daru łaski, zwłaszcza w ramach największego daru Ducha Świętego - Miłości. Nie można wykluczyć znaczenia modlitwy, zwłaszcza prośby o dar budowania wspólnoty w parafii. Urzeczywistnia

1 R. Łukaszyk, Dialog, w: Encyklopedia katolicka, t. III, Lublin 1985, kol. 1258.

2 Jan Paweł II, Homilia na Placu Zwycięstwa w Warszawie z dnia 2 czerwca 1979 r., w: Gaude Mater Polonia, Kraków 1980, s. 26. 
dialog Boga z człowiekiem także Liturgia i słowo Boże, zwłaszcza słuchane i przyjmowane jako słowo normatywne dla życia chrześcijańskiego.

\section{Wizja Kościoła, parafii i duszpasterstwa a dialog}

Możliwość dialogu w parafii zakłada określoną wizję teologiczną Kościoła i charakter pastoralnego modelu funkcjonowania parafii. W wizji piramidalnej Kościoła i parafii Soboru Trydenckiego ${ }^{3}$ zwolennicy uskuteczniania dialogu nie mieli łatwego zadania. Być może nie było z tym problemu na płaszczyźnie wiary, zwłaszcza w środowisku autentycznej i pogłębionej duchowości. Gorzej już było w teologii, a jeszcze trudniej w praktyce Kościoła. Trzeba nadmienić, że Kościół przeszedł długą drogę ewolucji w refleksji nad sobą samym i swoim działaniem. Zasadniczy przełom w kształtowaniu się współczesnej wizji Kościoła przypada na wiek XX, w którym uwarunkowania społeczne spowodowały w krajach tradycyjnie katolickich poważnie zagrażający wspólnotom kościelnym kryzys żywotności. Refleksja Kościoła i teologów poszła w kierunku zdiagnozowania sytuacji i znalezienia przyczyn kryzysu w zaniku cechy wspólnotowości tradycyjnych parafii ${ }^{4}$. Postulatem pastoralnym stało się pilne szukanie antidotum na rysujące się pęknięcia we wspólnotach eklezjalnych. Rozeznawanie znaków czasu, potwierdzone na II Soborze Watykańskim i w epoce posoborowej, doprowadziły do nowej wizji parafii i duszpasterstwa, zakorzenionej w odnowionej eklezjologii. Według tej nowej wizji, Kościół to już nie tylko społeczność doskonała: societas perfecta, ale przede wszystkim Koinonia albo łac. Communio ${ }^{5}$. W istotnych cechach Communio zawiera się zaś aspekt trynitarny i personalistyczny dialog międzyosobowy zakorzeniony w wierze w Trójjedynego Boga; aspekt horyzontalny i wertykalny - dialog Boga z człowiekiem oraz miedzy ludźmi; aspekt misyjny - dialog miłości przynoszący owoce w postaci „rodzenia dzieci wiary". Tak określone Communio Kościoła może znaleźć konkretne wcielenie we wspólnocie parafii. Parafia, chociaż jako struktura jest wytworem rozwoju historycznego Kościoła ${ }^{6}$, w sensie teologicznym stanowi ona wydarzenie Kościoła w wymiarze lokalnym i urzeczywistnia w sobie Kościół uniwersalny we wszystkich jego istotnych cechach. Ta perspektywa

${ }^{3}$ Por. R. Kamiński, Wprowadzenie do teologii pastoralnej, w: tenże (red.), Teologia pastoralna, t. 2, Lublin 2002, s. 18-20.

${ }^{4}$ Por. W. Piwowarski, Próby rekonstrukcji wspólnoty parafialnej, w: tenże (red.), Socjologia religii, Lublin 1996, s. 123.

${ }_{5}^{5}$ W. Kasper, Kościót jako wspólnota. Refleksje nad eklezjologiczna ideq przewodniq Soboru Watykańskiego II, „Communio” 6 (1986), nr 4/34, s. 28-31.

${ }^{6}$ Por. R. Kamiński, Wstęp, w: tenże (red.), Teologia pastoralna, t. 2, s. 11. 
eklezjologiczna doprowadziła do zmian w modelu funkcjonowania parafii. Można zatem twierdzić, że Kościół urzeczywistnia się w niej jako Communio, co konkretnie w praktyce oznacza model parafii jako wspólnoty wspólnot. W tak funkcjonującej parafii realizują się określone zasady budowania kościelnej wspólnoty ${ }^{7}$, wśród których istotną rolę odgrywa dialog na różnych płaszczyznach.

Na czoło postulatów pastoralnych w celu budowania modelu parafii jako wspólnoty wspólnot wysuwa się potrzeba tworzenia środowisk chrześcijańskich. Środowisko wiary dojrzałej zakłada zaś u podstaw osobowy dialog, wzajemną wymianę darów oraz współuczestnictwo, współpracę i współodpowiedzialność. Podejście instytucjonalne i biurokratyczne w duszpasterstwie zostaje zastąpione podejściem środowiskowym. Polega to na personalistyczno-dialogicznym charakterze komunikacji i wzajemnych odniesień w kontaktach duszpasterskich.

Niemały wpływ na urzeczywistnianie wspólnoty dialogu w parafii posiada wreszcie styl kierowania parafią. Funkcja kierowania istotnie rzutuje nie tylko na atmosferę w każdej grupie społecznej, ale kształtuje model wzajemnych odniesień i tworzenie się określonego typu więzi interpersonalnych. Przy autorytarnym stylu kierowania parafią niemożliwy jest szczery dialog, panuje raczej atmosfera zastraszenia blokująca szczerość w relacjach. Sytuacja taka wpływa hamująco na podejmowanie inicjatywy i współodpowiedzialność. Dominuje monolog i dyktat zamiast współpracy i dialogu'. Również styl pasywny, nieuczestniczący lub nieingerujący w sprawowaniu funkcji kierowania, dystansujący się od podejmowania decyzji i uchylający się od odpowiedzialności, nie sprzyja twórczemu dialogowi. Więcej jest wtedy rywalizacji i walki o władzę i wpływy aniżeli rzeczywistego dialogu. W stylu natomiast partycypacyjnym zwanym też demokratycznym kryją się największe możliwości rozwijania dialogu wewnątrz grupy. Tego typu sprawowanie funkcji kierowania w parafii pozwala uskuteczniać dialog zarówno między duszpasterzami (hierarchią) a wiernymi świeckimi, jak i między samymi parafianami. W takim przypadku ma zastosowanie zasada pomocniczości, która, zgodnie zresztą z nauką społeczną Kościoła, powinna stanowić wraz z zasadą dobra wspólnego i solidarności podstawę rozwoju życia społecznego. Kościół jako rzeczywistość teologiczna budowana jest wprawdzie przez Ducha Świętego, jednakże współbrzmi takie budowanie z chrześcijańskimi normami etycznymi w życiu społecznym. One wyznaczają kryteria wzajemnych odniesień wszystkich uczestników dialogu w parafii.

${ }^{7}$ Por. M. Łaszczyk, Urzeczywistnianie Kościoła we wspólnocie w świetle pastoralnych zasad eklezjologii komunii, „Studia Włocławskie” 1 (1997), s. 263-271.

${ }^{8}$ Por. J. Mariański, Żyć parafia, Wrocław 1984, s. 76-78. 


\section{Uczestnicy i płaszczyzny dialogu wewnątrz-parafialnego}

Przeciętna parafia jako wspólnota charyzmatów i posług aktualizuje dialog między różnymi podmiotami i na różnych płaszczyznach. Można w niej mówić o współpracy duchownych i świeckich, o dialogu między parafianami różniącymi się stopniem zaangażowania w życie religijne i parafialne, na przykład mówimy o dialogu aktywnych parafian z użytkownikami, praktykujących z niepraktykującymi. Można też mówić o dialogu pokoleniowym na płaszczyźnie religijnej. Taki dialog odbywa się między proboszczem i wikariuszem w parafii, między rodzicami i dziećmi, między młodzieżą i starszymi. Jak przebiega ten dialog, co stanowi płaszczyznę wzajemnej konfrontacji i wymiany poglądów oraz wspólnego poszukiwania prawdy? W relacjach duchownych i świeckich w parafii istnieje daleko idące zróżnicowanie, od ścisłej współpracy do sytuacji konfliktowych, a nawet wzajemnego zwalczania. W tle tych kontaktów jest wizja Kościoła, jaką posiadają uczestnicy, poziom wiedzy religijnej, kultura osobista - uwarunkowania psychologiczne. Te ostatnie odgrywają dużą rolę zarówno po stronie świeckich, jak i duchownych. W dużej mierze przeciętni katolicy w Polsce postrzegają Kościół, kojarząc go z księdzem i parafialną instytucją religijną. Osobisty autorytet księdza ułatwia dialog. Na taki jednak autorytet trzeba długo pracować i nie pozwalać sobie na kryzys zaufania. Ludzie zaś stawiają wysoko poprzeczkę wymagań w stosunku do osób duchownych i chcieliby w księdzu widzieć idealny obraz człowieka. Przy tym trzeba zaznaczyć, że każdy ma własną wizję ideału, najczęściej dopasowaną do własnych i aktualnych w danej chwili potrzeb. Sprostać tym zadaniom i trafić w zapotrzebowania ludzi jest niezwykle trudno. $Z$ drugiej strony ksiądz dysponujący określoną wizją Kościoła i parafii czuje się w znacznej mierze funkcjonariuszem i reprezentantem Urzędu Nauczycielskiego i nie zawsze potrafi być wyrozumiały dla osób świeckich, którzy nie spełniają kryteriów i nie mieszczą się w ramach określonej, najczęściej prawem kanonicznym, wizji Kościoła. Dialog jednak jest możliwy. Istnieją po obydwu stronach ludzie otwarci, posiadający wyższy niż przeciętny poziom duchowości i kultury osobistej, zdolni podejmować dialog w każdej sytuacji, nawet w napięciach i konfliktach. Nie zawsze też mamy do czynienia z sytuacją konfrontacji. Wzajemne zaufanie może pojawiać się w pragnieniu współtworzenia jakiegoś dzieła ewangelizacyjnego, charytatywnego, czy w dziedzinie liturgii sprawowanej w parafii. Respektowanie kompetencji i otwartość na współpracę pozwala wspólnie planować działanie, wspierać dobre inicjatywy, dzielić odpowiedzialność i podejmować wspólne zadania ewangelizacyjne. Współcześnie w dobie postępującej laicyzacji żaden pojedynczy duszpasterz nie jest w stanie stawić czoła 
fali odpływu wiernych z Kościoła. Potrzeba uwiarygodnienia świadectwa chrześcijańskiego poprzez konkretną w parafii żywą wspólnotę wiary, kultu i miłości braterskiej, składającą się zarówno z duchownych, jak i świeckich, tzw. kościelną wspólnotę podstawową. Wobec praktykujących parafian i ich duszpasterzy stają nowe wyzwania: jeszcze większego współdziałania, większego dzielenia odpowiedzialności w rozwiązywaniu problemów, wspólnoty modlitwy i wspierania się wzajemnego zarówno w życiu duchowym, jak i w podejmowanych przedsięwzięciach duszpasterskich.

W dialogu wewnątrz-parafialnym istnieje również szerokie pole współpracy pomiędzy parafianami. Przeciętne postawy wiernych są zróżnicowane pod względem religijności i jej poszczególnych parametrów: wiedzy religijnej, moralności, więzi ze wspólnotą parafialną, doświadczenia wiary. Przynależący do parafii żyją też w zróżnicowanych warunkach pod względem statusu materialnego, wykształcenia, uwarunkowań środowiskowych, rodziny i sąsiedztwa. Ma to wpływ na zdolność do otwartości na innych oraz umiejętność dialogu i współpracy. Istnieje nadal silne zróżnicowanie pomiędzy środowiskiem wiejskim i miejskim, zamkniętym i otwartym kulturowo. Wydaje się na pierwszy rzut oka, że w środowiskach tradycyjnych obserwuje się postawy bardziej pasywne w sprawach typowo duszpasterskich, ale za to większe zaangażowanie w sprawach materialnych parafii i odwrotnie, że w środowiskach otwartych więcej jest postaw zaangażowanych i aktywnych w podejmowanych akcjach duszpasterskich przy jednocześnie mniejszym bezpośrednim zaangażowaniu w sprawy ekonomiczne parafii. Nie da się jednak już dzisiaj z całą jednoznacznością zweryfikować pozytywnie tej tezy. Wieś, podobnie jak miasto, szybko atomizuje się. Rozpadają się tradycyjne więzi i wartości. Nawet parafia wiejska nie pełni już - jak dawniej - swej funkcji integracyjnej. Pogłębiające się kontrasty ekonomiczne w społecznościach lokalnych, większa dostępność do dóbr kultury masowej i wszechobecny konsumpcjonizm przyczyniają się do wzrostu frustracji w postawach ludzi wierzących, izolowania się i obojętności na problemy innych. Odbija się to na zaangażowaniu w życie parafii i miejskich, i wiejskich - osłabieniu w spełnianiu praktyk religijnych oraz niechęci we włączaniu się do grup parafialnych, a nawet osłabieniu bezinteresownego udziału w okazyjnych formach pomocy i pracy w kościele. Nie zawsze więc udaje się nawiązać dialog pomiędzy aktywnymi parafianami a użytkownikami, pomiędzy praktykującymi i niepraktykującymi. Wyjątek stanowią tu niektóre nowe ruchy religijne, które - przeważnie jednak w miastach - potrafią formować swoich członków do różnych form dialogu, wychodzenia do ludzi dystansujących się od Kościoła i poszukiwania dróg wzajemnej współpracy9.

9 Por. M. Łaszczyk, Zagrożenia i szanse rozwoju stowarzyszeń i ruchów religijnych w Kościele, „Roczniki Teologiczne” XXXVIII-XXXIX (1991-1992), z. 6, s. 243-255. 
W dialogu międzypokoleniowym występują także elementy charakterystyczne dla naszej epoki. Wprawdzie kryterium wieku zawsze różnicuje partnerów dialogu do tego stopnia, że rzadko dialog ten pozbawiony jest napięć. W parafii w dalszym ciagu można zauważyć różnice w wizji Kościoła oraz $\mathrm{w}$ podejściu do wiary, moralności i obyczajów u starszego i młodszego pokolenia. Zauważa się to zarówno w relacjach między duchownymi, zwłaszcza między proboszczem, zwykle starszym wiekiem, a wikariuszem, jak i wśród starszych i młodszych parafian, a więc między rodzicami i ich dziećmi oraz w ogóle między młodzieżą a dorosłymi. Co stanowi wspólny mianownik konfliktów pokoleniowych we wspólnocie parafialnej? Jakie są możliwości nawiązania dialogu między młodszymi i starszymi członkami tej wspólnoty? Wydaje się, że wspólną cechą napięć jest brak zdolności słuchania siebie wzajemnie i niezrozumienie wynikające $\mathrm{z}$ różnego języka wypowiadania siebie. Są to jakby dwie szkoły z różnym programem nauczania i tylko niektóre lekcje są zbieżne. Uczniowie tych szkół dopiero muszą uczyć się języka komunikowania i w trudzie osiagać wzajemne porozumienie. Na pewno nie pomoże w dialogu metoda przemocy, walki i konfrontacji, skrajność i ekstremizm w poglądach, fundamentalizm w znaczeniu ideologicznym, izolacjonizm i zapatrzenie w siebie (egocentryzm), lekceważenie drugiej strony i poczucie wyższości, nadmierny emocjonalizm w reakcjach, zwłaszcza na sprzeciw drugiego. Starsi jednak i młodsi są sobie wzajemnie potrzebni. Starsi formują młodych najbardziej przez autentyczne świadectwo życia chrześcijańskiego w małżeństwie, w dziedzinie pracy zawodowej czy w kulturze zachowania. Doświadczenia młodych nie zawsze są pozytywne w tych dziedzinach. Starsi zaś potrzebują dynamizmu ludzi młodych, spontanicznego zaangażowania i otwartości na dobro, elastyczności w zdolności weryfikowania i zmiany postaw. Dialog więc pokoleniowy może w parafii jak najbardziej zaistnieć i przynieść pozytywne owoce.

\section{Dialog parafii z innymi grupami spolecznymi}

Na pierwszym miejscu wysuwa się w tym punkcie dialog parafii w ramach społeczności lokalnej wsi, gminy czy miasta. Konieczna jest otwartość parafii na globalne społeczeństwo, zwłaszcza współpraca i wymiana w płaszczyźnie kultury, dobroczynności, wychowania, oświaty, nauki, gospodarki a nawet polityki: polityki prorodzinnej, socjalnej itp. Wyraża się to najpierw w dialogu między duszpasterzami i radą parafialną a władzami samorządowymi. Owocna może okazać się współpraca we wszystkich wymienionych płaszczyznach. Społeczność ludzi wierzących stanowi najczęściej największą grupę w ramach społeczności lokalnej. W warunkach polskich dochodzi 
niekiedy do nakładania się tych dwu społeczności. Istnieją też inne organizacje i grupy mniejsze jak: partie polityczne, organizacje pożytku publicznego, szkoły i ośrodki wychowawcze, kluby i koła zainteresowań. W parafii mogą także działać mniejsze grupy dorosłych, młodzieży i dzieci: modlitewne, charytatywne, kulturalne, wychowawcze, formacyjne itp. W jakiej mierze dialog parafii we wszystkich jej strukturach z innymi grupami społecznymi byłby pożyteczny dla niej samej i dla ogółu społeczeństwa? Korzyści zapewne są po obydwu stronach. Parafia zyskuje wsparcie często materialne od bogatszego najczęściej samorządu, zwłaszcza w sprawach ważnych dla ogółu społeczeństwa. Są to elementy infrastruktury w terenie otaczającym kościół i budynki parafialne, kaplice filialne oraz cmentarz parafialny. Parafia może wnieść swój wkład materialny w inwestycje dla dobra publicznego, a przynajmniej udzielić moralnego i intelektualnego wsparcia działaniom pożytecznym dla życia ludzi. Dobra współpraca obydwu podmiotów może pozytywnie wpłynąć na relacje i wzajemne odniesienia mieszkańców, aktywizować ich i jednoczyć.

Kolejnym miejscem dialogu może być współpraca parafii z organizacjami i instytucjami pozarządowymi, działającymi na polu oświatowym, kulturalnym, charytatywnym i społeczno-politycznym. Szkoły z natury rzeczy powinny być w dialogu z parafią, nie tylko w dziedzinie katechezy szkolnej, ale także w dziedzinie integralnego wychowania młodego człowieka. Działalność kulturalna szkół, organizacji i instytucji powinna spotykać się również $\mathrm{z}$ otwartością parafii, a dialog $\mathrm{w}$ tej dziedzinie może być prowadzony nawet ponad podziałami światopoglądowymi czy politycznymi. Do takich płaszczyzn dialogu zalicza się też działalność charytatywna, która poszerzona o współpracę różnych instytucji może przynieść pozytywne owoce. W jakiej mierze jednak jest możliwy dialog parafii z partiami i ugrupowaniami politycznymi? Kościół nie może bowiem firmować swym autorytetem i utożsamiać się z jakąkolwiek partią polityczną. O ile względy ideologiczne raczej nie pozwalają na dialog daleko idący, poza stroną etyczną tej działalności, o tyle wszelka inna działalność dla dobra wspólnego może w lokalnych społecznościach spotkać się z pozytywnym zaangażowaniem pod wielorakim względem także parafii i jej struktur. Wszelkie wyróżnianie jednak członków jednej partii, jednego obozu politycznego w parafii sprawia, że Kościół usytuowuje się po którejś stronie walki politycznej i przyczynia się do jeszcze większego dzielenia ludzi pod względem ideologicznym zamiast łączyć (por. KDK 76). Wzajemne kontakty duszpasterzy i polityków muszą być nacechowane bezinteresownością i służyć dobru wspólnemu. 


\section{Możliwość dialogu parafii z niewierzącymi i dystansującymi się od Kościoła}

W dialogu we wspólnocie parafialnej trudno pominąć osoby niewierzące i dystansujące się od Kościoła mieszkające na terenie parafii lub osoby okazyjnie odwiedzające parafię. W tej grupie są to najczęściej osoby ochrzczone, ale zaniedbane religijnie. W takiej sytuacji nie zawsze jest w ogóle chęć dialogu po obu stronach. Brak zazwyczaj wzajemnego kontaktu sprzyja stereotypom myślenia jednych o drugich. Nie zawsze te wzajemne opinie są dobre. Łatwo im poddać się, gdyż niewielkie są możliwości ich weryfikacji. To skutkuje zamknięciem na dialog. Na płaszczyźnie jednak poza-religijnej, tzw. neutralnej, może być prowadzony twórczy dialog i współpraca w wielu dziedzinach życia lokalnej społeczności. Z kolei to wzajemne otwarcie pozwala przełamać opory i ubogacić się wzajemnie. Duszpasterze poznają lepiej środowisko, z którym prawie nigdy się nie spotykają. Niewierzący i niepraktykujący zaś mogą skonfrontować z rzeczywistością swoje lub przejęte od innych opinie o Kościele i księżach. Czasami również może powstać $\mathrm{u}$ nich autentyczne zainteresowanie sprawami wiary.

Warunkiem koniecznym dialogu parafii z niewierzącymi i niepraktykującymi jest wzajemny szacunek do odrębnych przekonań, nie obrażanie nikogo, nawet wroga, kultura bycia i atmosfera wzajemnej życzliwości. Jest to wymóg ducha II Soboru Watykańskiego, który otworzył Kościół i jego struktury na dialog ze światem takim, jaki on jest ${ }^{10}$. Zakłada to umiejętność wzajemnego słuchania, uczenia się języka komunikacji - zarówno werbalnego i niewerbalnego, nade wszystko zaś wzajemną uczciwość i szczerość. Postawione wysokie wymagania moralne różniącym się bardzo stronom dialogu wskazują na to, że tylko nieliczni w parafii będą zdolni do twórczej współpracy. Powstają bowiem łatwo bariery i trudności przy zróżnicowanych postawach osób, zwłaszcza o skrajnych przekonaniach i ekstremalnych zachowaniach.

\section{Możliwości i trudności w dialogu parafialnym}

Na początku trzeba zaznaczyć, że dialog jest możliwy, jeśli wśród jego uczestników jest dobra wola szukania prawdy, a w relacjach międzyosobo-

${ }^{10}$ Przykładem jest dialog między-religijny, dialog ekumeniczny w łonie wyznań chrześcijańskich, otwarcie się na osoby żyjące w niesakramentalnych związkach małżeńskich, dialog z różnymi kulturami (inkulturacja), dialog z niewierzącymi i poszukującymi prawdy, dialog z wszystkimi ludźmi dobrej woli. 
wych minimum życzliwości i wzajemnego zaufania. Konieczny jest też szacunek do drugiego człowieka, bez względu na jego światopogląd i przekonania. Bez tych nadrzędnych podstaw, właściwie dyspozycji moralnych, nie da się prowadzić dialogu w żadnej wspólnocie, a tym samym w parafii. Po drugie, możliwość dialogu warunkują też czynniki narzędne, innymi słowy narzędzia dialogu jak: język komunikacji, umiejętność słuchania siebie i empatii, formacja duchowa i kultura partnerów $\mathrm{w}$ dialogu ${ }^{11}$. O ile teoretycznie łatwo na ogół akceptować i zgadzać się z wymienionymi warunkami prawdziwego dialogu, to jednak w praktyce pojawiają się liczne trudności.

Kryzys zaufania i ograniczenia w szczerym szukaniu prawdy w dużej mierze spowodowane są przemianami społecznymi. Rozpad więzi międzyludzkich i tradycyjnych systemów wartości, ściśle związanych z chrześcijaństwem, doprowadził do dużych trudności w dialogu na płaszczyźnie religijnej. Sprawy moralności, doktryny i zachowań religijnych, niegdyś nie budzące powszechnie zastrzeżeń w ich przyjmowaniu i zachowywaniu, stały się przedmiotem wątpliwości i dyskusji, co najwyżej selektywnego wyboru. Spotyka się to z rosnącym permisywizmem, to jest ze społecznym przyzwoleniem na takie postawy do tego stopnia, że stroną obarczaną winą w konflikcie są domagający się klarowności postaw moralnych i religijnych. $\mathrm{Na}$ tym tle wybuchają często konflikty pokoleniowe dotyczące wiary i moralności, zwłaszcza zauważalne w rodzinach wielopokoleniowych. Przekłada się to na dialog między duchownymi a świeckimi parafianami. W sprawach zasadniczych najostrzej przebiegają starcia między bezkompromisowo wymagającymi duszpasterzami a zaniedbanymi czy marginalnymi parafianami. Obracają się one wokół spraw obrzędów pogrzebowych, wymagań w przygotowaniu dzieci do I Komunii, młodzieży do sakramentu bierzmowania czy narzeczonych do sakramentu małżeństwa. Najtrudniej wtedy o dialog, bo z jednej strony na przeszkodzie stoją przeciwstawne cele - każda ze stron posiada własną wizję celu, który chce osiagnąć: inną wizję sakramentów, inną wizję hierarchii wartości, inną wizję Kościoła, inną koncepcję życia chrześcijańskiego. $\mathrm{Z}$ drugiej strony braki natury osobowościowej rozmówców - brak kultury osobistej, brak zaufania, lęk przed osądzeniem i wytknięciem upokarzających wad, nadwrażliwość emocjonalna, różne kompleksy i zranienia - jeszcze bardziej utrudniają dialog.

Oprócz wymienionych czynników, postawa kierującego parafią duszpasterza rzutuje na możliwość lub niemożliwość dialogu. Największą przeszkodą i niebezpieczeństwem dla rozwoju dialogu w parafii jest autorytaryzm i paternalizm w sprawowaniu funkcji kierowania. Duchownym niekiedy

${ }^{11}$ Por. J. Przybyłowski, Dialog pastoralny, „Ateneum Kapłańskie” 602 (2009), s. $47-48$. 
trudno pozbyć się nawyków dyrygowania, traktowania parafian z góry, lekceważąco czy w sposób infantylny. Świeckim wiernym zaś łatwo przychodzi uchylanie się od współodpowiedzialności za parafię i przerzucanie całej troski o Kościół duchowy i sprawy materialne parafii na duchowieństwo. Czy wyżej wymienione trudności w dialogu parafialnym da się pokonać?

Jako pierwsze antidotum można postulować potrzebę tworzenia forum dialogu i wypracowywanie metod współdziałania. W parafii skuteczną rolę w podejmowaniu dialogu spełniają parafialna rada duszpasterska i rada ekonomiczna. Współpraca $\mathrm{w}$ ramach tych struktur przebiega nie tylko na płaszczyźnie wymiany myśli i poglądów na różne sprawy parafii, ale także może angażować członków - reprezentantów różnych grup społecznych, w praktycznym działaniu. Ponadto metody współdziałania wypracowuje każda parafia w oparciu o własną tradycję i aktualne możliwości, zwłaszcza w zakresie odpowiednio zaangażowanych, uformowanych i kompetentnych współpracowników świeckich. Dobrze także radzą sobie w dialogu grupy parafialne i ruchy religijne, które formują swych członków do otwartości i uczą języka religijnego. Formacja duchowa poprzez środowisko wiary jest znacznie pogłębiona, aniżeli tylko kształtowana przez tradycję i obyczaje chrześcijańskie przekazywane - zresztą coraz słabiej - przez rodzinę lub tradycyjne formy duszpasterstwa masowego. Rozwój form duszpasterstwa grupowego staje się podstawowym postulatem odnowy parafii ${ }^{12}$. Nie uda się bez nich nowa ewangelizacja środowisk zlaicyzowanych i ludzi dystansujących się od Kościoła.

Zatem dialog jest na pewno możliwy i wskazany we wspólnocie parafialnej. Stwarza on szansę budowania wspólnoty osób na wzór Ewangelii, czyli urzeczywistniania Kościoła w konkretnym miejscu i czasie, czyli tak zwanego Kościoła lokalnego jako wspólnoty wiary, liturgii i miłości braterskiej. Dialog jest szansą upodmiotowienia wszystkich członków Kościoła, w którym każdy może czuć się jak we własnym domu. Wtedy dialogujący bardziej identyfikuje się z parafią, intensywniej przeżywa swoje chrześcijaństwo i doświadcza Kościoła w konkretnej wspólnocie lokalnej. Podsumowując można stwierdzić, że dialog we wspólnocie parafialnej jest potrzebny, możliwy i konieczny.

12 Por. M. Łaszczyk, Stowarzyszenia i ruchy eklezjalne jako szansa urzeczywistniania się Kościoła w parafialnej wspólnocie wspólnot, „Studia Włocławskie” 6 (2003) s. 296-304. 


\section{Is there a possible dialogue in a parish community? (Summary)}

The author of the article is asking questions in the title: is there a possible dialogue in a parish community? The reply is trying to find in introducing such problems as: the theological vision of the Church, the parish and pastoral service according to the dialogue; participants and areas of the dialogue inside the parish, the dialogue of the parish with different social groups; the possibility of the dialogue of the parish with atheistic and distancing oneself from the Church; possibilities and problems in the parish dialogue. The article analyses dialogue in according to the determined vision of the Church and the parish as a community of communities. It explains the relations and the connections with the style of holding the manager function in a parish-pastoral service, shows participants of the dialogue and different plains communications as well as potential conflicts and also problems of the dialogue between generations. It seems, that the dialogue in the parish, from a point of view of building parish bond, to be not only possible but it is needed and even necessary. 